Images dans le monde ibérique et ibéricoaméricain

$8 \mid 2015$

L'Histoire et ses récits entre images, fictions et paratextes

\title{
De la búsqueda del hombre perdido a la revelación del mexicano: o cómo el Laberinto de la soledad traza su camino desde la poesía
}

\section{Ina Salazar}

\section{OpenEdition}

\section{Journals}

Edición electrónica

URL: http://journals.openedition.org/agedor/301

DOI: $10.4000 /$ agedor.301

ISSN: 2104-3353

Editor

Laboratoire LISAA

Referencia electrónica

Ina Salazar, « De la búsqueda del hombre perdido a la revelación del mexicano: o cómo el Laberinto de la soledad traza su camino desde la poesía », L'Âge d'or [En línea], 8 | 2015, Publicado el 01 febrero

2016, consultado el 04 mayo 2019. URL : http://journals.openedition.org/agedor/301 ; DOI : 10.4000/ agedor.301

L'Âge d'or. Images dans le monde ibérique et ibéricoaméricain 
Ina $S A L A Z A R$

Université de Caen-Basse Normandie, LASLAR

\title{
De la búsqueda del hombre perdido a la revelación del mexicano: o cómo el Laberinto de la soledad traza su camino desde la poesía
}

\begin{abstract}
Résumé : à partir d'un texte intitulé « Poésie de solitude et poésie de communion » écrit par Octavio Paz quelques années avant Le labyrinthe de la solitude et que l'auteur définit comme l'équivalent poétique de ce dernier, je me propose d'examiner la manière dont la poésie possède une fonction médiatrice au sein de cet essai et travaille en profondeur le discours critique ouvrant sur une dimension ontothéologique.
\end{abstract}

Mots-clés : communion - solitude - poésie - révélation - sacré - langage - origine

Resumen: A partir de un texto titulado « Poesía de soledad y poesía de comunión » escrito por Octavio Paz unos años antes que El laberinto de la soledad y que el autor define como el equivalente poético de este último, me propongo analizar la mediación de la poesía en el ensayo y la manera como trabaja en profundidad el discurso crítico haciendo palpable una dimensión ontoteológica.

Palabras clave: comunión - soledad - poesía - revelación - sagrado - origen - lenguaje

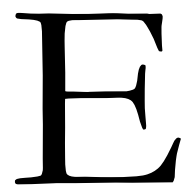

n la entrevista concedida a Alfred Mac Adam el 10 de octubre de 1990, Octavio Paz, al abordar el tema del Laberinto de la soledad, su contexto y su concepción, define como «equivalente poético» de nuestro ensayo, un texto titulado "Poesía de soledad y poesía de comunión", que fue leído en 1942 por el autor en el marco de una serie de conferencias organizadas en torno a san Juan de la Cruz para celebrar el cuarto centenario de su nacimiento ${ }^{1}$. Sorprende que este texto que marca según A. Stanton el punto culminante de lo que definió como la "prehistoria estética de Octavio Paz", escrito unos siete años antes que el Laberinto de la soledad, sea considerado como un "equivalente" más que como un «antecedente». Estas son las palabras de Paz:

(es) el equivalente poético de El laberinto de la soledad pues presenta mi visión del hombre, que es muy sencilla. Existen dos situaciones para cada ser humano. La primera es la soledad que experimentamos al nacer. Nuestra primera experiencia es la de la orfandad, y no es sino hasta más tarde cuando descubrimos su contrario, el sentimiento filial. La segunda situación consiste en lo siguiente: por el hecho de ser arrojados al mundo, como dice Heidegger, sentimos que debemos encontrar lo que los budistas llaman «la otra orilla». Es la sed de comunión. Creo que la filosofía y la religión nacen de esta situación o predicamento original. Cada país y cada individuo procura resolver este conflicto en formas diferentes. La función de la poesía ante nuestra situación original consiste en ser un puente entre la soledad y la comunión ${ }^{3} \ldots$

\footnotetext{
${ }^{1}$ El texto apareció al año siguiente en el №5 de la revista El Hijo Pródigo (15/08/1943).

2 STANTON, Antony, «La prehistoria estética de Octavio Paz: los escritos en prosa (1931-1943) », Literatura Mexicana 2,2, 1991, p. 23-55.

${ }^{3}$ PAZ, Octavio, Obra completa, Miscelánea III, entrevistas, FCE, 2003, p. 340.
} 
A primera vista podemos deducir por estas explicaciones que si "Poesía de soledad y poesía de comunión" aparece como el equivalente poético del Laberinto de la soledad es porque en él cuajan los significados y valores fundamentales que Paz le asigna a la dialéctica articuladora del ensayo, es decir, soledad/comunión y la identificación de esas dos situaciones para cada ser humano, siendo la primera la soledad que experimentamos al nacer y al sentirnos arrojados en el mundo, abandonados y huérfanos, la segunda, la sed de comunión y búsqueda de la unidad perdida. Sin embargo, estos planteamientos que ya están en ciernes en muchos de sus escritos prácticamente desde que empezó a escribir, y más precisamente en Vigilias: diario de un soñador (1935-1945) y en artículos aparecidos en diversas revistas como Barandal, El Hijo Pródigo, Taller y que en esta conferencia adquieren una expresión más acabada, no son como parece decirlo Paz tan centrales en "Poesía de soledad y poesía de comunión". En efecto, en este texto el autor defiende sobre todo la necesidad de la poesía en las sociedades modernas occidentales y occidentalizadas, secularizadas y por ende desacralizadas, y en un siglo XX determinado por el capitalismo y la ideología burguesa. Plantea la urgencia de atender a ese apetito humano de readquirir la original y perdida unidad ${ }^{4}$ afirmando que solo la poesía puede hacerlo, pues mediante la palabra, el poeta procura hacer sagrado el mundo.

La importancia que Paz le otorga en la entrevista a esta visión "sencilla" del hombre para definir "Poesía de soledad y poesía de comunión" como equivalente poético del Laberinto de la soledad es problemática pues parece evacuar el objetivo central de este, o sea, ser antes que nada una meditación sobre la historia de México y también parece borrar el contexto vivencial que alimenta la redacción del Laberinto de la soledad, lo determinantes que fueron los años que separan ambos textos para su concepción: primero, la partida de Paz a finales de 1943 a los EEUU, con la beca Guggenheim, la estancia de dos años y la experiencia de extranjería vivida como "un sacudimiento espiritual", y revelación de un México visto "desde la otra orilla", experiencia sin la cual dice el mismo Paz, "no hubiera escrito nunca El laberinto de la soledad". Y luego, la estancia parisina ulterior, entre 1946 y 1949, años de la posguerra en que aprovecha plenamente la efervescencia cultural y filosófica que caracteriza a la capital francesa, compenetrándose con el surrealismo, el psicoanálisis y el existencialismo. Son años sumamente estimulantes para el mexicano como tiempo de encuentros y aprendizajes y asimismo como experiencia que agudiza y exacerba la conciencia de pertenencia al país a partir de un fuerte sentimiento de nostalgia. Recordemos que todo ello lleva a Paz en "El hombre es un ser que se pregunta" (1990) a definir El laberinto de la soledad como "una obra fechada", no solo porque está marcada por las experiencias del hombre Paz, sino porque su redacción responde a la necesidad de una reflexión con respecto a una entrada de México en la modernidad que según Paz luego se revelaría como "fuente de tantos fracasos" .

El interés que presenta la equivalencia efectuada por Paz entre «Poesía de soledad y poesía de comunión» y el ensayo de 1949, radica en el hecho que hace visibles las tensiones entre historicidad y pensamiento mítico-poético existentes en El laberinto de la soledad: por un lado, la integración del tiempo histórico y de la historia personal como claves de comprensión e interpretación, y por el otro, el hacer de la dialéctica soledad/comunión un esquema de base, un predicado original, invariable: "el ritmo doble de la soledad y la comunión, el sentirse solo, escindido y el desear reunirse con los otros y con nosotros mismos (que es) aplicable a todos los hombres y a todas las sociedades" ${ }^{\prime}$. Si bien esta doble entrada (histórica y mítico-poética) apunta a la universalidad, a huir de todo particularismo, a esquivar o no encarar la inevitable condición periférica, y querer entender e insertar a México y los mexicanos en la historia universal -

\footnotetext{
${ }^{4}$ Las citas de este texto pueden encontrarse en el anexo que reproduce la conferencia en su totalidad.

${ }^{5}$ En « Poesía de circunstancia » entrevista con César Salgado (agosto de 1987), op. cit. p. 526.

${ }^{6}$ El laberinto de la soledad, Madrid, Cátedra, 1998, p. 572-573.

${ }^{7}$ En « Poesía de circunstancia », op. cit. p. 524.

${ }^{8}$ Op. cit. 572.
} 
"somos, por primera vez en nuestra historia, contemporáneos de todos los hombres" - refleja también la convicción, la intención de Paz de otorgarle a la palabra, y, en este caso, a la palabra a través del ensayo, no solo una función de conocimiento sino también de ser arma activa de transformación del hombre, de lucha, de recuperación de un sentido profundo perdido por una modernidad desmemoriada y árida que "ha despojado al hombre de su esencia humana para convertirlo en mercancía". Desde esta perspectiva, El laberinto de la soledad apela a esa función mediadora de la poesía enunciada en "Poesía de soledad y poesía de comunión", a ese poder de "consagrar la experiencia de los hombres y las relaciones entre el hombre y el mundo, entre el hombre y la mujer, entre el hombre y su propia conciencia", es decir, de actuar como "una mediación eficaz"10. Sería un error pensar que la presencia de la poesía en El laberinto de la soledad se limita, se circunscribe al empleo de sus figuras retóricas, al despliegue de imágenes, a un sofisticado trabajo de la lengua. Si bien todo eso está y de manera poderosa y recurrente, en magnífica convivencia además con un lenguaje pensante, es porque está construyéndose un fondo trascendente, o sea, otorgándole existencia dentro del espacio del ensayo y del pensamiento crítico a esa «fuerza, apetito que quiere ser hasta el límite y más allá del límite del ser, hambre de eternidad y de espacio» propia del hombre. Ya que para Paz la poesía, en su parentesco original con la religión tiende como ella a la comunión; "las dos parten de la soledad e intentan, mediante el alimento sagrado, romper la soledad y devolver al hombre su inocencia". Sin embargo no son lo mismo: a diferencia de la religión, "la poesía rompe el lazo (social) al consagrar una relación individual, al margen, cuando no en contra, de la sociedad», a diferencia de la religión también su arraigo es absolutamente terrenal: "No quiere salvar al hombre, ni construir la ciudad de Dios: pretende darnos el testimonio terrenal de una experiencia" y en ello se ve la impronta de Rainer María Rilke. La poesía es la que puede ser mediación para que el hombre moderno pueda olvidar su circunstancia original de soledad y desarraigo y sentirse en comunión, un estado de plenitud cuyas formas más acabadas son el éxtasis místico y el amor dichoso. Si la poesía tiene como misión intentar ser puente, ser mediación es porque entabla con el mundo y con la realidad una relación otra. La poesía, dice Paz, no aspira a dominar ni a sujetar la realidad como sí lo intenta el conocimiento (científico, racionalista). La poesía acepta y sabe que la realidad es «intocable», porque es "todo lo que somos, todo lo que nos envuelve, nos sostiene y, simultáneamente, nos devora y alimenta", por ello, se nos escapa de manera permanente. La poesía a diferencia del conocimiento, no se dirige a saber, a la posesión de lo que se contempla, solo intenta "abismarse en su objeto" en un anhelo de fusión y de olvido, de "disolución del ser en lo otro". Esta manera de ser y de estar en el mundo y la realidad, que implica como dice Paz "despilfarro vital", hace que la poesía entre en tensión con la sociedad, pues se mueve en las antípodas de la "conservación", del "orden" y de la "economía", eso que "la sociedad capitalista llama sus ideales", de ahí su carácter heterodoxo y disidente.

Por consiguiente, la importancia, la incidencia de "Poesía de soledad y poesía de comunión" en El laberinto de la soledad no se mide solo por la identificación del predicado de base, el estado de soledad original y el deseo de comunión como aspiración propia de todos los hombres y mujeres, sino que afirma la necesidad de la poesía como mediación, instalándola en el seno mismo de la dialéctica soledad/comunión que es fuerza motriz del ensayo. La presencia de esta dialéctica así como la necesidad de la poesía, tal como es concebida por Paz, capaz de resacralizar el mundo y la realidad y de entablar con éstos una relación otra (contemplación y abismamiento), son determinantes en la (compleja) definición del Laberinto de la soledad, pues dibujan en filigrana una dimensión ontoteológica. Si «Poesía de soledad y poesía de comunión», texto de 1942, echa luces sobre El laberinto de soledad es porque hace más visible, más comprensible esta dimensión. Podríamos plantearlo de la siguiente manera jugando silogísticamente con las palabras: porque la poesía es necesaria al hombre para recuperar un estado de inocencia perdida, le es necesaria al ensayista que es Paz para la revelación de México y

${ }^{9}$ Ibid., p. 340.

${ }^{10}$ GIRAUD, Paul-Henri Octavio, Paz vers la transparence, PUF, 2002. 
del mexicano. Utilizo el término «revelación» porque es clave y constante a lo largo del ensayo, algo de ello hay también en la manera como habla Paz de la redacción de El laberinto de la soledad"lo escribí en unos pocos meses, como quien se cuenta a sí mismo un secreto callado durante siglos"11 -; la noción de revelación hace comprensible el lazo entre poesía y pensamiento, creación y critica: la empresa de Paz en El laberinto de la soledad no es simple descubrimiento o conocimiento, es partir de una realidad velada, oculta, para ir al encuentro del "otro México" "12 de ese "México enterrado pero vivo"13, lo que no solo va a ser exploración arqueológica y desenmascaramiento sino también búsqueda de verdades hasta entonces desconocidas y que pueden ser aprehendidas gracias al lenguaje indirecto y plurivalente de la poesía. Vamos a intentar demostrarlo.

Como lo hemos observado, la dialéctica soledad/comunión vertebra la meditación sobre la historia de México que es El laberinto de la soledad, y Paz hace de la cuestión del origen un centro secreto de la ansiedad y angustia del mexicano, asociando el devenir histórico con el movimiento del hombre que busca su filiación, su origen. Ello implica una relectura y desciframiento de la historia de México en sus diferentes épocas y momentos y Paz lo hace en tanto que intelectual mexicano de mediados del siglo XX, preocupado por el presente y el futuro de su país, convencido de que si el país tiene que encontrar su propio camino hacia la modernidad, el pasado no debe ser un obstáculo sino un punto de partida. Para ello echa mano del psicoanálisis con el objeto de identificar la cuestión del origen como nudo traumático -padre conquistador y madre indígena violada-, así como los fantasmas contra los cuales lucha el mexicano. Sin embargo, la atracción de Paz por la cuestión del origen se nutre también del valor que esta tiene para la poesía a partir del romanticismo. En "Poesía de soledad y poesía de comunión", el autor reivindica el quehacer de los poetas que padecen la nostalgia de un estado perdido, en el que el hombre es uno con el mundo y con sus creaciones. Estos son Novalis, Baudelaire, Nerval y Lautréamont a los que él llama románticos herméticos. Ellos "muestran el camino", dice, pues de esa "nostalgia surge el presentimiento de un estado futuro, de una edad inocente". Y termina apuntando: "Poetas originales no tanto -como dice Chesterton- por su novedad sino porque descienden a los orígenes". Paz va a leer la Historia desde la necesidad de la reconciliación con los orígenes, del restablecimiento de lazos. Ello es flagrante en los dos cabos que tensan la dialéctica soledad/comunión, ese «perpetuo separarse y unirse» en clave mexicana (que por lo demás va a asumir múltiples formas y figuras: la cortesía y el hermetismo como soledad cerrada, el gusto por las fiestas como búsqueda de comunión, etc...). En El laberinto de la soledad se configuran las dos situaciones mayores que se responden como "visiones" del poeta: por un lado, la situación de soledad del mexicano moderno (que se da) "bajo la gran noche de piedra de la Altiplanicie, poblada todavía de dioses insaciables" como efecto de «sentirse arrancado del seno de esa realidad, a un tiempo creadora y destructora, Madre y Tumba", (en referencia al pasado prehispánico) y por haber "olvidado el nombre, la palabra que lo liga a todas esas fuerzas en que se manifiesta la vida"14. Por el otro, en tanto que expresión mayor de comunión, en respuesta a esta situación de escisión y orfandad (soledad), se destaca de la historia mexicana la revolución de 1910 porque es "inmersión de México en su propio ser" 15 , reconquista del pasado, siendo esencial el significado y valor que le asigna dentro de la revolución, al zapatismo, «paradójica combinación de tradicionalismo y pujanza revolucionaria»" que es "revelación, el salir a flote de ciertas realidades escondidas y reprimidas" ${ }^{\prime 17}$. El valor de la revolución no es ideológico sino que radica en su carácter instintivo, el ser "estallido" que es "revelación de una realidad anterior a las

\footnotetext{
${ }^{11}$ En "Solo a dos voces", Obra completa, Miscelánea III, p. 526.

12 En "Postdata", El laberinto de la soledad, Cátedra, p. 389.

13 Ibid., p. 421.

14 Op. cit. p. 155.

15 Ibid., p. 292.

${ }^{16}$ Ibid., p. 428

${ }^{17}$ Ibid.
} 
jerarquías, las clases, la propiedad"18. A Paz le apasiona (esa es su palabra) el zapatismo porque lo identifica como manifestación o acercamiento al estado original (que el religioso o los enamorados alcanzan) enunciado en "Poesía de soledad y poesía de comunión" y que define ahí como "descenso a estados cada vez más antiguos y desnudos", participación otra vez de ese "estado en el que la muerte y la vida, la necesidad y la satisfacción, el sueño y el acto, la palabra y la imagen, el tiempo y el espacio, el fruto y el labio, se confunden en una sola realidad". Como se ve en la cita anterior, "revelación" y "revolución» parecen ir juntos. Esta asociación se repite a menudo y encabeza el subcapítulo que dedica Paz a este hecho histórico: "la revolución mexicana es un hecho que irrumpe en nuestra historia como una verdadera revelación de nuestro ser" ${ }^{\prime \prime}$. Esta palabra asociada a la revolución le asigna a esta la posibilidad de situarse más allá del hecho histórico, en otra dimensión que quizá solo la religión y la poesía conocen:

La Revolución (...) es una revuelta y una comunión, un trasegar viejas sustancias dormidas, un salir al aire muchas ferocidades, muchas ternuras y muchas finuras ocultas por el miedo a ser. ¿Y con quién comulga México en esta sangrienta fiesta? Consigo mismo, con su propio ser. México se atreve a ser. La explosión revolucionaria es una portentosa fiesta en la que el mexicano, borracho de sí mismo, conoce al fin, en abrazo mortal, al otro mexicano. ${ }^{20}$

Este fragmento cierra el capítulo VI "De la independencia a la revolución", título que no puede ser más histórico y por ende en las antípodas de los territorios de la poesía. Sin embargo, las palabras que leemos nos dicen lo contrario, no solo rehúyen la anécdota, los datos y eventos históricos, lo puramente factual, sino que el pensamiento se nutre esencialmente de la metáfora "viejas sustancias dormidas" -, o el oxímoron - "sangrienta fiesta", "abrazo mortal" - y de las figuras que construyen un ritmo - repeticiones y variaciones fónicas, aliteraciones de ataque, asonancias que moldean una matriz sonora significante como en "con quién comulga México en esta sangrienta fiesta?"- y que son lo propio de la poesía. Esta se manifiesta no para brindar un conocimiento razonado sino para transmitir la violenta experiencia de la comunión. Es lo que sucede asimismo en la cita precedente con la poderosa imagen/visión de "la gran noche de piedra de la Altiplanicie, poblada todavía de dioses insaciables", la cual a través de una forma-ritmo que es antes que nada plástica transmite la experiencia de la soledad como inmensidad aterradora, sugiriendo sin nombrarla, a través de la imagen, la omnipresencia de la pirámide.

En El laberinto de la soledad el lenguaje y la palabra no están al servicio del pensamiento o de la idea, la poesía no es una retórica, en ella y gracias a ella se gesta el pensamiento como ritmo, en el sentido que le da el lingüista Emile Benveniste ${ }^{21}$, a través de la palabra griega original rbuthmos que designa la forma en el instante en que es asumida por lo que es móvil, fluido, forma que no tiene una consistencia orgánica permanente, una organización siempre sujeta a cambios posibles, es decir, una organización viva. No es para nada fortuito que ritmo sea una palabra clave de la dialéctica de la soledad y comunión - "el ritmo doble de la soledad y la comunión, el sentirse solo, escindido y el desear reunirse con los otros y con nosotros mismos (que es) aplicable a todos los hombres y a todas las sociedades" - y que sea un elemento recurrente en esta meditación sobre la historia de México que es El laberinto de la soledad: "no es arbitrario ver nuestra historia como un proceso regido por el ritmo -o la dialéctica- de lo cerrado y lo abierto, de la soledad y la comunión...". Paz sabe perfectamente cuáles son los necesarios pasajes entre poesía y pensamiento y la función determinante que tiene el ritmo, si pensamos en las aclaradoras palabras de Hölderlin al respecto: «Pour que l'esprit devienne poésie, il faut qu'il porte en lui le mystère d'un rythme inné. C'est dans ce rythme seul qu'il peut vivre et devenir visible »22.

\footnotetext{
18 Ibid., p 294.

${ }^{19}$ Ibid., p. $279-280$.

${ }^{20}$ Ibid., p. 293-294.

21 BENVENISTE, Émile, «La notion de 'rythme' dans son expression linguistique »(1951) dans Problèmes de linguistique générale, Gallimard, 1966, p. 327-335.

${ }^{22}$ Hölderlin citado por BLANCHOT, Maurice, L'espace littéraire, Paris, Idées Gallimard, 1955 p. 303.
} 
La mediación de la poesía le es necesaria al ensayista Paz para ir a buscar ese "México enterrado pero vivo", (ese) "universo de imágenes, deseos e impulsos sepultados que están en los mexicanos, hombres y mujeres" ${ }^{23}$. Hay en esta empresa, por supuesto, un afán manifiesto de rigor científico, en ese examinar no tanto las ideas explícitas sino las creencias implícitas, las creencias enterradas. En ese (describir) "el mundo de represiones, inhibiciones, recuerdos, apetitos y sueños que ha sido y es México" 24 , en la identificación de una realidad escondida y que hace daño, está la investigación del historiador, está el trabajo de arqueología que hace el psicoanálisis, está la crítica moral. Sin embargo, la búsqueda de ese "otro México", de (esa) "realidad compuesta de diferentes estratos y que alternativamente se pliega y se despliega, se oculta y se revela" 25 requiere de las "visiones del poeta" 26 , va a apelar a la capacidad del poeta, reivindicada por los románticos, de "ver el mundo como tejido de símbolos y de relaciones entre esos símbolos" como una realidad cifrada que hay que captar y revelar. Cifra y desciframiento son las dos caras de este quehacer cuya clave es poética, y que identificamos en el buceo que son los capítulos «Máscaras mexicanas» o "Los hijos de la Malinche", como también en esa vuelta atrás, esa revisión de la Historia de México que efectúa en "Conquista y colonia" o "De la independencia a la revolución". El Paz ensayista necesita al Paz poeta a partir del momento en que se admite que detrás de la manifestación visible existe una realidad oculta que debe/espera ser revelada:

Todas las historias de nuestros pueblos son simbólicas...la historia, sus acontecimientos y sus protagonistas remiten a otra historia oculta, son la manifestación visible de una realidad oculta. Vivimos la Historia como si fuera una representación de máscaras que dibujan en el escenario figuras enigmáticas. ${ }^{28}$

¿Quién más que el poeta puede identificar esas figuras enigmáticas, leer en el libro cifrado de la realidad, revelar la secreta y oculta dimensión de la realidad?

Ya nos decía el Paz de "Poesía de soledad y poesía de comunión" que (el) "testimonio (de la poesía) es la revelación de una experiencia en la que participan todos los hombres, oculta por la rutina y la diaria amargura". Es decir que la poesía es facultad de revelación de la faz oculta de la realidad y por ende de la historia. La plurivalencia de la metáfora de la "máscara", tan importante en los planteamientos del ensayo es bastante elocuente de la complejidad del Laberinto de la soledad, de su manera de hablar a través de distintas voces, y sobre todo de su rechazo a concebir monolítica y unívocamente el mundo, las relaciones entre los hombres así como con el pasado. En efecto, la máscara remite al ocultamiento y este es, significa, al mismo tiempo, enigma y falsedad, o sea, misterio y apariencia, una cosa y la otra: "El carácter de México, como el de cualquier otro pueblo, es una ilusión, una máscara, al mismo tiempo, es un rostro real. Nunca es el mismo y siempre es el mismo." 29

Solo la poesía puede hablar de esa manera, es decir, ser portadora y expresar la plurivocidad de la vida y de la historia, aquí la mexicana. En se sentido, si para ser revelación y leer en el libro del universo y de la realidad Paz se apoya, se inspira, en el romanticismo, su exploración va a echar mano de las prácticas surrealistas para ir a buscar la imagen venida de las profundidades, del subconsciente, va a acudir a estas otras "visiones" que proponen los surrealistas - estos "taumaturgos maestros del arte de la resurrección y la aparición de fantasmas" - para identificar y hacer palpable en la transfiguración, el deseo reprimido, la imaginación enterrada por las instituciones y las prohibiciones, en un trabajo de "arqueología" que, como el mismo Paz lo ha reivindicado, le debe mucho al psicoanálisis. En este plano, en este quehacer, se

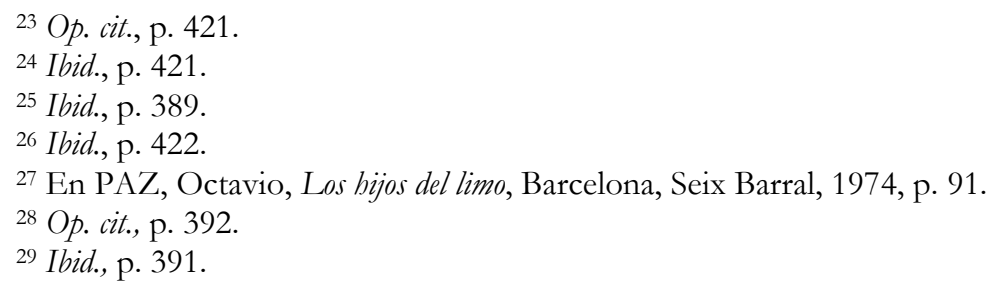


percibe que la poesía como mediación no solo sacraliza: es un lenguaje que aunque parezca paradójico contribuye a la dimensión crítica que opera eficazmente a lo largo de la obra. Para "revelar el sueño de los hombres es preciso no renunciar a la conciencia" decía Paz en "Poesía de soledad y poesía de comunión" y esta afirmación nos permite ver actuar dialécticamente en El laberinto de la soledad inocencia y conciencia así como crítica y creación. Este ensayo es, en ello, una espléndida demostración de la convicción paciana de que creación y crítica viven en simbiosis perpetua.

La crítica - dice - no es el sueño pero nos enseña a soñar y a distinguir entre los espectros de las pesadillas y las verdaderas visiones. La crítica es el aprendizaje de la imaginación en su segunda vuelta, la imaginación curada de fantasía y decidida a afrontar la realidad del mundo. La crítica nos dice que debemos aprender a disolver los ídolos: aprender a disolverlos dentro de nosotros mismos. Tenemos que aprender a ser aire, sueño en libertad. ${ }^{30}$

De modo que ir a buscar al "otro México» que alternativamente se pliega y se despliega, se oculta y se revela"31 es simultáneamente arqueología y visión poética, es revelación sin dejar de ser por ello desenmascaramiento. En el lenguaje, operan creación y crítica y Paz no duda en dinamitar el lenguaje, como lo hace con la popular expresión "hijos de la chingada", con la figura del "macho" o del "gran chingón" para descubrir lo que está oculto. Hace lo que él llama "crítica del lenguaje", es decir, una "operación activa", un arte "crítico y pasional", que se focaliza en las "imágenes dobles de la banalidad y lo maravilloso cotidianos". Se trata de un ejercicio subversivo y perturbador, que no es poesía pero que como ella conoce el "poder mágico del lenguaje" 32 . Si le otorga especial atención a las "palabras prohibidas, secretas sin contenido claro", es porque ve en ellas un "lenguaje sagrado, como el de los niños, la poesía y las sectas (pues) cada letra y cada sílaba está animadas de una vida doble, al mismo tiempo, luminosa y oscura, que nos revela u oculta" ${ }^{\prime 3}$. Adquiere particular relevancia esta operación activa de minar el lenguaje en el contexto del México postrevolucionario en que el discurso revolucionario se ha momificado y se ha vaciado de sus principios y valores. A través de esta crítica del lenguaje no solo se denuncia a una sociedad que se corrompe sino que se actúa pues la formulación crítica está animada por la convicción de que algo se puede desde el lenguaje mismo. "Cambiar el lenguaje no es cambiar el mundo pero el mundo no cambia si antes no cambiamos el lenguaje" ${ }^{34}$. Este es un propósito revolucionario y poético porque cree en el poder de la palabra.

El laberinto de la soledad abriga entonces aspiraciones que sobrepasan la simple meditación. Hay fe en la capacidad de acción de la palabra, y ésta se perfila en dos dimensiones o planos diferentes. La necesidad de subvertir la doxa, las creencias, los estereotipos, y arrancar las máscaras por un lado y, por el otro, la voluntad de combatir el "desierto de la modernidad" al que lo condena el «destierro de lo sagrado». El "cambiar la vida" rimbaldiano, que los surrealistas hicieron suyo, es asumido por Paz también de una manera muy personal en "Poesía de soledad y poesía de comunión": "La poesía, ha dicho Rimbaud, quiere cambiar la vida, no intenta embellecerla, como piensan los estetas y los literatos, ni hacerla más justa o buena, como sueñan los moralistas. Mediante la palabra, mediante la expresión de su experiencia, procura hacer sagrado el mundo". En El laberinto de la soledad opera este poder pues se propone una palabra que no se contenta con constatar sino que es (o quiere ser) en sí activa mediación a la manera del poema:

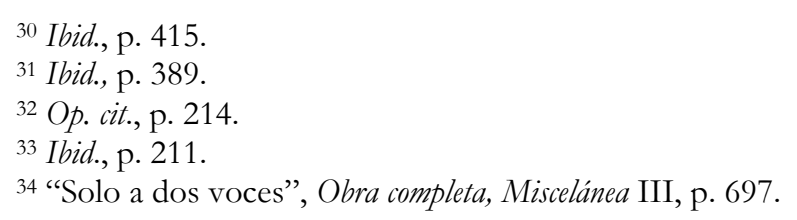


el poema no sólo es una realidad verbal: también es un acto. El poeta dice y, al decir, hace...en el fondo de esta idea vive todavía la antigua creencia en el poder de las palabras: la poesía pensada y vivida como una operación mágica destinada a transmutar la realidad... La concepción de la poesía como magia implica una estética activa; quiero decir, el arte deja de ser exclusivamente representación y contemplación: también es intervención sobre la realidad. Si el arte es un espejo del mundo, ese espejo es mágico: lo cambia. ${ }^{35}$

No solo descifrar sino apropiarse de figuras y motivos, creencias y mitos, reconocerlos, nombrarlos, e insertarlos en un cosmos textual, en una red constante de correspondencias y analogías con irradiaciones múltiples, a partir de la dialéctica de la soledad y la comunión, de lo abierto y lo cerrado como estructuras subyacentes o predicados originales, y en que se responden los símbolos míticos universales y mexicanos como el laberinto, la pirámide, la máscara, en que los personajes o hechos históricos como el conquistador Cortés y la Malinche madre violada, como Emiliano Zapata y la revolución de 1910, despliegan sus valores simbólicos más allá del tiempo cronológico, en que las manifestaciones mexicanas de la fiesta y la muerte afirman el poder siempre vigente de la dimensión mítica.

El laberinto de la soledad encierra en sí el designio de «desgarrar las formas que asfixian»al mexicano y de "crear una nueva Forma" que acoja "la sustancia de nuestros sueños y el sentido de nuestros actos" 36 , de ser una forma que responda a esa necesidad de "imaginar una edad de oro de la que el grupo social fue arrancado", es decir, reactivar al existir como palabra semejante al poder de los antiguos Mitos. Esta intención me parece manifiesta en las últimas páginas del Laberinto de la soledad y en el soplo que podríamos definir casi como "profético" o "visionario" que adopta su palabra, momento quizá en que más se aleja de una lengua meramente reflexiva:

El hombre moderno tiene la pretensión de pensar despierto. Pero este despierto pensamiento nos ha llevado por los corredores de una sinuosa pesadilla, en donde los espejos de la razón multiplican las cámaras de tortura. Al salir, acaso descubriremos que habíamos soñado con los ojos abiertos y que los sueños de la razón son atroces. Quizá entonces empezaremos a soñar otra vez con los ojos cerrados. ${ }^{37}$

Estas que son las últimas palabras del ensayo y que aluden de manera indirecta, haciendo uso de la metáfora y de la alusión goyesca, a la realidad del hombre moderno y sus horrores, se alejan de la reflexión y parecen dirigir un mensaje a través de un locutor que se proyecta en el futuro y se integra en un nosotros humano y mexicano pero que sin embargo se distingue por ser el "creador" del laberinto de la soledad, de ese laberinto ideado quizás, para que entre sus páginas y gracias a sus palabras, al poder de la palabra, el lector, el mexicano vislumbren el camino del centro perdido.

\footnotetext{
${ }^{35}$ Los hijos del limo, p. 94.

36 Op. cit., p. 361.

${ }^{37}$ Ibid.
} 


\section{Anexo: "Poesía de comunión y poesía de soledad"}

La realidad - todo lo que somos, todo lo que nos envuelve, nos sostiene y, simultáneamente, nos devora y alimenta - es más rica y cambiante, más viva, que los sistemas que pretenden contenerla. A cambio de reducir la rica y casi ofensiva espontaneidad de la naturaleza a la rigidez de nuestras ideas, la mutilamos de una parte de sí, la más fascinante: su naturalidad. El hombre, al enfrentarse con la realidad, la sojuzga, la mutila y la somete a un orden que no es el de la naturaleza - si es que ésta posee, acaso, equivalente a lo que llamamos orden- sino el del pensamiento. Y así, no es la realidad lo que realmente conocemos, sino esa parte de la realidad que podemos reducir a lenguaje y conceptos. Lo que llamamos conocimiento es el saber que tenemos sobre cualquier cosa para dominarla y sujetarla.

No quiero decir, naturalmente, que la técnica sea el conocimiento. Pero aun cuando sea imposible extraer de todo conocimiento una técnica - o sea: un procedimiento para transformar la realidad - todos los conocimientos son la expresión de una sed de apoderarnos, en nuestros propios términos y para nuestros propios fines, de esa intocable realidad. No es exagerado llamar a esta actitud humana una actitud de dominación. Como un guerrero, el hombre lucha y somete a la naturaleza y a la realidad. Su instinto de poder no solo se expresa en la guerra, en la política, en la técnica; también en la ciencia y en la filosofía, en todo lo que se ha dado en llamar, hipócritamente, conocimiento desinteresado.

No es ésta la única actitud que el hombre puede asumir frente a la realidad del mundo y de su propia conciencia. Su contemplación puede no poseer ninguna consecuencia práctica y de ella es posible que no se pueda derivar ningún conocimiento, ningún dictamen, ninguna salvación o condenación. Esta contemplación inútil, superflua, inservible, no se dirige a saber, a la posesión de lo que se contempla, sino que solo intenta abismarse en su objeto. El hombre que así contempla no se propone saber nada; sólo quiere un olvido de sí, postrarse ante lo que ve, fundirse, si es posible en lo que el asombro ante la realidad lo lleva a divinizarla; la fascinación y horror lo mueven a unirse con su objeto. Quizá la raíz de esta actitud de adoración sea el amor, que es un instinto de posesión del objeto, un querer, pero también un anhelo de fusión, de olvido, y disolución del ser en "lo otro". En el amor no solo interviene el instinto que nos impulsa a sobrevivir o a reproducirnos: el instinto de la muerte, verdadero instinto de perdición, fuerza de gravedad del alma, también es parte de su contradictoria naturaleza. En él alientan el arrobo silencioso, el vértigo, la seducción del abismo, deseo de caer infinitamente y sin reposo, cada vez más hondo, y la nostalgia de nuestro origen, oscuro movimiento del hombre hacia su raíz, hacia su nacimiento. Porque en el amor la pareja intenta participar otra vez de ese estado en el que la muerte y la vida, la necesidad y la satisfacción, el sueño y el acto, la palabra y la imagen, el tiempo y el espacio, el fruto y el labio, se confunden en una sola realidad. Los amantes descienden hacia estados cada vez más antiguos y desnudos; rescatan al animal humillado y al vegetal soñoliento que yace en cada uno de nosotros; y tienen el presentimiento de la pura energía que mueve el universo y de la inercia en que se transforma el vértigo de esa energía.

A estas dos actitudes pueden reducirse, con todos los peligros de tan excesiva simplificación, las innumerables y variadas posturas del hombre frente a la realidad. Las dos se dan con cierta pureza en la magia y la religión de las sociedades arcaicas (aunque, en rigor, ambas sean inseparables, pues en toda actividad mágica hay elementos religiosos y a la inversa). Si el sacerdote se postra ante el dios, el mago se alza "frente a la realidad y, convocando a los poderes ocultos, hechizando a la naturaleza, obliga a las fuerzas rebeldes a la obediencia. Uno suplica y ama; otro, adula o coacciona. Ahora bien, la operación poética ¿es una actividad mágica o religiosa? Ni lo uno ni lo otro. La poesía es irreductible a cualquier otra experiencia. Pero el espíritu que la expresa, los medios de que se vale, su origen y su fin, muy bien pueden ser mágicos o religiosos. La actitud ante lo sagrado cristaliza en el ruego, en la oración, y su más intensa y profunda manifestación es el éxtasis místico: el entregarse a lo absoluto y confundirse con Dios. La religión - en este sentido - es diálogo, relación amorosa con el Creador. También el poeta lírico entabla un diálogo con el mundo; en ese diálogo hay dos situaciones extremas: una, de soledad; otra, de comunión. El poeta siempre intenta comulgar, unirse (reunirse, mejor dicho), con su objeto: su propia alma, la amada, Dios, la naturaleza... La poesía mueve al poeta hacia lo desconocido y la poesía lírica, que principia como un íntimo deslumbramiento, termina en la comunión o en la blasfemia. No importa que el poeta se sirva de la magia de las palabras, del hechizo del lenguaje, para solicitar a su objeto: nunca pretende utilizarlo, como el mago, sino fundirse a él, como el místico.

En la fiesta o representación religiosa el hombre intenta cambiar de naturaleza, despojarse de la suya y participar de la divina. La misa no solo es una actualización o representación de la Pasión de 
Jesucristo; es también una liturgia, un misterio en donde el diálogo entre el hombre y su Creador culmina en la comunión. Si mediante el bautismo los hijos de Adán adquieren esa libertad que les permite dar el salto mortal entre el estado natural y el estado de gracia, por la comunión los cristianos pueden, en las tinieblas de un misterio inefable, comer la carne y beber la sangre de su Dios. Esto es, alimentarse con una substancia divina, con la sustancia divina. El festín sagrado diviniza, lo mismo al azteca que al cristiano. No es diverso este apetito al del enamorado y al del poeta. Novalis ha dicho: "El deseo sexual no es quizá sino un deseo disfrazado de carne humana." El pensamiento del poeta alemán, que ve en «la mujer el alimento corporal más elevado», nos ilumina acerca del carácter de la poesía y del amor: se trata, por medio del canibalismo ritual, de readquirir nuestra naturaleza paradisíaca.

No es extraño que la poesía haya provocado el recelo, cuando no el escándalo, de algunos espíritus que veían latir en ella, en una actividad profana, el mismo apetito y la misma sed que mueven al hombre religioso. Frente a la religión, que solo existe si se socializa en una iglesia, en una comunidad de fieles, la poesía se manifiesta solo si se individualiza, si encarna en un poeta. Su relación con lo absoluto es privada y personal. Religión y poesía tienden a la comunión; las dos parten de la soledad e intentan, mediante el alimento sagrado, romper la soledad y devolver al hombre su inocencia. Pero en tanto que la religión es profundamente conservadora puesto que torna sagrado el lazo social al convertir en iglesia a la sociedad, la poesía rompe el lazo al consagrar una relación individual, al margen, cuando no en contra, de la sociedad. La poesía siempre es disidente. No necesita de la teología ni de la clerecía. No quiere salvar al hombre, ni construir la ciudad de Dios: pretende darnos el testimonio terrenal de una experiencia. Respuesta a las mismas preguntas y necesidades que la religión satisface, la poesía se nos aparece como una forma secreta, ilegal, irregular, de la religión: como una heterodoxia, no porque no admita los dogmas, sino porque se manifiesta de un modo privado y muchas veces anárquico. En otras palabras: la religión es siempre social - excepto cuando se transforma en mística -, mientras que la poesía, al menos en nuestra época, es individual.

¿Qué clase de testimonio es el de la palabra poética, extraño testimonio de la unidad del hombre y el mundo, de su original y perdida identidad? Ante todo, el de la inocencia innata del hombre, como la religión es el de su perdida inocencia. Si una afirma el pecado, la otra lo niega. El poeta revela la inocencia del hombre, su testimonio solo vale si llega a transformar su experiencia en expresión, esto es, en palabras. Y no en cualquier clase de palabras, ni en cualquier orden, sino en un orden que no es el del pensamiento, ni el de la conversación, ni el de la oración. Un orden que crea sus propias leyes y su propia realidad: el poema. Por ese, ha podido decir un crítico francés que "en tanto que el poeta tiende a la palabra, el místico tiende al silencio". Esa diversidad de direcciones distingue, al fin, la experiencia mística de la expresión poética. La mística es una inmersión en lo absoluto: la poesía es una expresión de lo absoluto o de la desgarrada tentativa para llegar a él. ¿Qué pretende el poeta cuando expresa su experiencia? La poesía, ha dicho Rimbaud, quiere cambiar la vida, no intenta embellecerla, como piensan los estetas y los literatos, ni hacerla más justa o buena, como sueñan los moralistas. Mediante la palabra, mediante la expresión de su experiencia, procura hacer sagrado el mundo; con la palabra consagra la experiencia de los hombres y las relaciones entre el hombre y el mundo, entre el hombre y la mujer, entre el hombre y su propia conciencia. No pretende hermosear, santificar o idealizar lo que toca, sino volverlo sagrado. Por eso no es moral o inmoral; justa o injusta; falsa o verdadera; o fea. Es, simplemente, poesía de soledad o de comunión. Porque la poesía, que es un testimonio del éxtasis, del amor dichoso, también lo es de la desesperación. Y tanto como un ruego puede ser una blasfemia.

La sociedad moderna no puede perdonar a la poesía su naturaleza: le parece sacrílega. Y aunque ésta se disfrace, acepte comulgar en el mismo altar común y luego justifique con toda clase de razones su embriaguez, la conciencia social la reprobará siempre como un extravío y una locura peligrosa. El poeta tiende a participar en lo absoluto, como el místico; y tiende a expresarlo, corno la liturgia y la fiesta religiosa. Esta pretensión lo convierte en un ser peligroso pues su actividad no beneficia a la sociedad; verdadero parásito, en lugar de atraer para ella las fuerzas desconocidas que la religión organiza y reparte, las dispersa en una empresa estéril y antisocial. En la comunión el poeta descubre la fuerza secreta del mundo, esa fuerza que la religión intenta canalizar y utilizar, a través de la burocracia eclesiástica y el poeta no solo la descubre y se hunde en ella: la muestra en toda su aterradora y violenta desnudez al resto de los hombres, latiendo en su palabra, viva en ese extraño mecanismo de encantamiento que es el poema. ¿Habrá que agregar que esa fuerza, alternativamente sagrada o maldita; es la del éxtasis, la del vértigo, que brota como una fascinación en la cima del contacto carnal o espiritual? En lo alto de ese contacto y en la profundidad de ese vértigo el hombre y la mujer tocan lo absoluto, el reino en donde los contrarios se reconcilian y la vida y la muerte pactan en unos labios que se funden. El cuerpo y el alma, en ese instante, 
son lo mismo y la piel es como una nueva conciencia, conciencia de lo infinito, vertida hacia lo infinito... El tacto y todos los sentidos dejan de servir al placer o al conocimiento; cesan de ser personales; se extienden, por decirlo así, y lejos de constituir las antenas, los instrumentos de la conciencia, la disuelven en lo absoluto, la reintegran a la energía original. Fuerza, apetito que quiere ser hasta el límite y más allá del límite del ser, hambre de eternidad y de espacio, sed que no retrocede ante la caída, antes bien busca palpar en su exceso vital, en su desgarramiento de sí, ese despeñarse sin fin que le revela la inmovilidad y la muerte, el reino negro del olvido, hambre de vida, sí, pero también de muerte.

La poesía es la revelación de la inocencia que alienta en cada hombre y en cada mujer y que todos podemos recobrar apenas el amor ilumina nuestros ojos y nos devuelve el asombro y la fertilidad. Su testimonio es la revelación de una experiencia en la que participan todos los hombres, oculta por la rutina y la diaria amargura. Los poetas han sido los primeros que han revelado que la eternidad y lo absoluto no están más allá de nuestros sentidos sino en ellos mismos. Esta eternidad y esta reconciliación con el mundo se producen en el tiempo y dentro del tiempo, en nuestra vida mortal, porque el amor y la poesía no nos ofrecen la inmortalidad ni la salvación. Nietzsche decía: "No la vida eterna, sino la eterna vivacidad: eso es lo que importa." Una sociedad como la nuestra, que cuenta entre sus víctimas a sus mejores poetas; una sociedad que solo quiere conservarse y durar; una sociedad, en fin, para la que la conservación y el ahorro son las únicas leyes y que prefiere renunciar a la vida antes que exponerse al cambio, tiene que condenar a la poesía, ese despilfarro vital, cuando no puede domesticarla con toda clase de hipócritas alabanzas. y la condena, no en nombre de la vida, que es aventura y cambio, sino en nombre de la máscara de la vida: en nombre del instinto de conservación.

En ciertas épocas la poesía ha podido convivir con la sociedad y su impulso ha alimentado las mejores empresas de ésta. Poesía, religión y sociedad forman una unidad viviente y creadora en los tiempos primitivos. El poeta era mago y sacerdote; y su palabra era divina. Esa unidad se rompió hace milenios - precisamente en el momento en que la división del trabajo creó una clerecía y nacieron las primeras teocracias - pero la escisión entre poesía y sociedad nunca fue total. El gran divorcio comienza en el siglo XVIII y coincide con el derrumbe de las creencias que fueron el sustento de nuestra civilización. Nada ha sustituido al cristianismo y desde hace dos siglos vivimos en una suerte de interregno espiritual. En nuestra época la poesía no puede vivir dentro de lo que la sociedad capitalista llama sus ideales: las vidas de Shelley, Rimbaud, Baudelaire o Bécquer son pruebas que ahorran todo razonamiento. Si hasta fines del siglo pasado Mallarmé pudo crear su poesía fuera de la sociedad, ahora toda actividad poética, si lo es de verdad, tendrá que ir en contra de ella. No es extraño que para ciertas almas sensibles la única vocación posible sean la soledad o el suicidio; tampoco es extraño que para otras, hermosas y apasionadas, las únicas actividades poéticas imaginables sean la dinamita, el asesinato político o el crimen gratuito. En ciertos casos, por lo menos, hay que tener el valor de decir que se simpatiza con esas explosiones, testimonio de la desesperación a que nos conduce un sistema social basado solo en la conservación de todo y especialmente de las ganancias económicas.

La misma fuerza vital, lúcida en medio de su tiniebla, mueve al poeta de ayer y al de hoy. Solo que ayer era posible la comunión, gracias quizás a esa misma Iglesia que ahora la impide y habrá que decirlo: para que la experiencia se realice otra vez, será menester un hombre nuevo y una sociedad en la que la inspiración y la razón, las fuerzas irracionales y las racionales, el amor y la moral, lo colectivo y lo individual, se reconcilien. Esta reconciliación se da plenamente en San Juan de la Cruz. En el seno de esa sociedad en la que, acaso por última vez en la historia, la llama de la religiosidad personal pudo alimentarse de la religión de la sociedad, San Juan realiza la más intensa y plena de las experiencias: la de la comunión. Un poco más tarde esa comunión será imposible.

Las dos notas extremas de la poesía lírica, la de la comunión y la de la soledad, las podemos contemplar con toda su verdad en la historia de nuestra poesía. Nuestra lengua posee dos textos igualmente impresionantes: los poemas de San Juan y un poema de Quevedo, "Lágrimas de un penitente", poco estudiado hasta ahora por la crítica. Los de San Juan de la Cruz relatan la experiencia mística más profunda de nuestra cultura; no parece necesario extenderse sobre su significación porque son de tal modo perfectos que impiden toda tentativa de análisis poético. Naturalmente que no me refiero a la imposibilidad del análisis psicológico, filosófico estilístico, sino a la absurda pretensión que intenta explicar la poesía; la poesía, cuando alcanza la plenitud del "Cántico espiritual”, se explica por sí misma. No sucede lo mismo con los poemas de Quevedo. En las silvas y sonetos que forman las "Lágrimas de un penitente". Quevedo expresa la certidumbre de que el poeta ya no es uno con sus creaciones: está mortalmente dividido. Entre la poesía y el poeta, entre Dios y el hombre, se opone algo muy sutil y muy poderoso: la conciencia. y lo que es más significativo: la conciencia de la conciencia, la conciencia de sí. Quevedo 
expresa este estado demoníaco en dos versos: Las aguas del abismo / donde me enamoraba de mí mismo. Al principio del poema el poeta, pecador lúcido, se niega a ser salvado, se rehúsa a la gracia, prendido a la hermosura del mundo. Frente a Dios se siente solo y rechaza la redención, hundido en las apariencias: Nada me desengaña, / el mundo me ba hechizado.

Mas el pecador se da cuenta de que el mundo que lo encanta y al que se siente prendido con tal amor... no existe. La nada del mundo se le revela como algo real, de suerte que se siente enamorado de la nada. No es, sin embargo, la hermosura vacía e inexistente del mundo la que le impide ir más allá de sí y comulgar, sino su conciencia de sí. Este rasgo da un carácter excepcional al poema de Quevedo en el paisaje poético del siglo XVII; hay otros poetas más inspirados, más perfectos y puros, pero en ninguno alienta esta lucidez ante su propio desgarramiento. Lucidez que no hay más remedio que llamar "baudeleriana", En efecto, Quevedo afirma que la conciencia de sí es un saberse en el mal y en la nada, una gozosa conciencia del mal. Así, atribuye un contenido pecaminoso a la conciencia, no tanto por lo que peca en sus imaginaciones sino porque pretende sustentarse en sí misma, bastarse sola y sola saciar su sed de absoluto. Mientras San Juan ruega y suplica al amado. Quevedo es solicitado por su Dios; pero prefiere perderse y perderlo, antes que ofrecerle el único sacrificio que acepta: el de su conciencia. Al final del poema surge la necesidad de la expiación, que consiste en la humillación del yo: solo a este precio es posible la reconciliación con Dios. La historia de esta reconciliación da la impresión de ser un artificio retórico y teológico, ya porque la comunión no se haya producido realmente, ya porque el poeta no haya podido expresar la intensidad con que ha relatado su encantamiento y el goce fúnebre que le proporciona saberse en la nada del pecado, en la nada de sí mismo. En realidad, la respuesta de Quevedo es intelectual y estoica: se abraza a la muerte, no para recobrar la vida sino como resignación.

Entre estos dos polos de inocencia y conciencia, de soledad y comunión, se mueve toda poesía. Los hombres modernos, incapaces de inocencia, nacidos en una sociedad que nos hace naturalmente artificiales y que nos ha despojado de nuestra substancia humana para convertirnos en mercancías, buscamos en vano al hombre perdido, al hombre inocente. Todas las tentativas valiosas de nuestra cultura, desde fines del siglo XVIII, se dirigen a recobrarlo, a soñarlo. Incapaces de articular en un poema esta dualidad de conciencia e inocencia (puesto que corresponde a antagonismos irreductibles de la historia), la sustituimos por un rigor externo, puramente verbal, o por el balbuceo del inconsciente. La sola participación del inconsciente en un poema lo convierte en un documento psicológico; la sola presencia del pensamiento, con frecuencia vacío o especulativo, lo deshabita. Ni discursos académicos ni vómitos sentimentales. ¿Y qué decir de los discursos políticos, de las arengas, de los editoriales de periódico, que se enmascaran con el rostro de la poesía?

Y sin embargo, la poesía sigue siendo una fuerza capaz de revelar al hombre sus sueños y de invitarlo a vivirlos en pleno día. El poeta expresa el sueño del hombre y del mundo y nos dice que somos algo más que una máquina, un instrumento, un poco más que esa sangre que se derrama para enriquecer a los poderosos o sostener a la injusticia en el poder, algo más que mercancía y trabajo. En la noche soñamos y nuestro destino se manifiesta, porque soñamos lo que podríamos ser. Somos ese sueño y solo nacimos para realizarlo. Y el mundo - todos los hombres que ahora sufren o gozan - también sueña y anhela vivir a plena luz su sueño. La poesía, al expresar estos sueños, nos invita a la rebelión, a vivir despiertos nuestros sueños: a ser no ya los soñadores sino el sueño mismo.

Para revelar el sueño de los hombres es preciso no renunciar a la conciencia. No un abandono, sino una mayor exigencia consigo mismo, se le pide al poeta. Queremos una forma superior de la sinceridad: la autenticidad. En el siglo pasado un grupo de poetas, que representan la parte hermética del romanticismo - Novalis, Nerval, Baudelaire, Lautréamont - nos muestran el camino. Todos ellos son los desterrados de la poesía, los que padecen la nostalgia de un estado perdido, en el que el hombre es uno con el mundo y con sus creaciones. $\mathrm{Y}$ a veces de esa nostalgia surge el presentimiento de un estado futuro, de una edad inocente. Poetas originales no tanto -como dice Chesterton- por su novedad sino porque descienden a los orígenes. Ellos no buscaron la novedad, esa sirena que se disfraza de originalidad; en la autenticidad rigurosa encontraron verdadera originalidad. En su empresa no renunciaron a tener conciencia de su delirio, osadía que les ha traído un castigo que no vacilo en llamar envidioso: en todos ellos se ha cebado la desdicha, ya en la locura, ya en la muerte temprana o en la fuga de la civilización. Son los poetas malditos, sí, pero son algo más también: son los héroes vivientes y míticos de nuestro tiempo, porque encarnan -en sus vidas misteriosas y sórdidas y en su obra precisa e insondable- toda la claridad de la conciencia y toda la desesperación del apetito. La seducción que sobre nosotros ejercen estos maestros, nuestros únicos maestros posibles, se debe a la veracidad con que encarnaron ese propósito que intenta unir dos tendencias paralelas del espíritu humano: la conciencia y la inocencia, la experiencia y la 
expresión, el acto y la palabra que lo revela. O para decirlo con las palabras de uno de ellos: El matrimonio del Cielo y del Infierno.

México, 1942.

Este texto fue leído en un ciclo de conferencias organizado por la Editorial Séneca para conmemorar el cuarto centenario del nacimiento de San Juan de la Cruz. 